Bella D.R.S. · E. Suminar · A. Nuraini · A. Ismail

\title{
Pengujian efektivitas berbagai jenis dan konsentrasi sitokinin terhadap multiplikasi tunas mikro pisang (Musa paradisiaca $\mathbf{L}$.) secara in vitro
}

\section{The experiment of effectiveness with concentration of cytokinin on micro shoot multiplication banana (Musa paradisiaca $L$.) on in vitro culture}

Diterima : 15 Juli 2016/Disetujui : 10 Agustus 2016 / Dipublikasikan : 30 Agustus 2016

CDepartment of Crop Science, Padjadjaran University

\begin{abstract}
The use of banana sucker continuously as a material of conventional propagation technic reduces quality and it takes a long time due to the increasing of disease accumulation. Therefore, the fast propagation by in vitro culture is needed. The aim of this experiment was to find out the best type and concentration of cytokinins for growth and development banana 'Kepok Kuning' in vitro. The experiment was carried out from October to December 2015 at Seed Technology Tissue Culture Laboratory of Agriculture Faculty, Universitas Padjadjaran. Completely Randomized Design (CRD) with eight treatments are the types and concentration of cytokinine was used in this experiment $(2 \mathrm{mg}$ $\mathrm{L}^{-1} \mathrm{BAP}, 4 \mathrm{mg} \mathrm{L}^{-1} \mathrm{BAP}, 2 \mathrm{mg} \mathrm{L}^{-1} 2$-iP, $4 \mathrm{mg} \mathrm{L}^{-1} 2-$ iP, 0,08 $\mathrm{mg} \mathrm{L}^{-1} \mathrm{TDZ}, 0,2 \mathrm{mg} \mathrm{L}^{-1} \mathrm{TDZ}, 2 \mathrm{mg} \mathrm{L}^{-1} \mathrm{Kn}$, $4 \mathrm{mg} \mathrm{L}^{-1} \mathrm{Kn}$ ). The results showed that $2 \mathrm{mg} \mathrm{L}^{-1}$ BAP was effective in increasing the explant shoot percentage $(\%)$ and length of shoot $(\mathrm{cm})$.
\end{abstract}

Keywords : Effectivity · Kepok kuning ·

Multiplication · Banana $\cdot$ Cytokinins $\cdot$ Shoot

Sari Perbanyakan tanaman pisang secara konvensional dengan menggunakan bonggol atau anakan (sucker) secara terus menerus dapat menurunkan kualitas dan memerlukan waktu lama serta meningkatkan terjadinya serangan penyakit. Oleh karena itu, suatu upaya untuk menghasilkan bibit yang memiliki kualitas baik dalam waktu yang cepat dapat menggunakan kultur in vitro. Percobaan ini bertujuan untuk

\footnotetext{
Dikomunikasikan oleh Agus Wahyudin

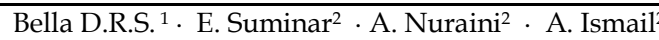

${ }^{1}$ Mahasiswa Program Studi Agroteknologi, Fakultas

Pertanian, Universitas Padjadjaran

${ }^{2}$ Dosen Fakultas Pertanian, Universitas Padjadjaran

Jl. Raya Jatinangor Km. 21 Jatinangor, Sumedang 45363

Email: dian.ratnasari2406@gmail.com
}

memperoleh laju multiplikasi yang tinggi dengan penggunaan salah satu jenis dan konsentrasi sitokinin pada kultur in vitro tanaman pisang kepok kuning. Percobaan dilakukan pada bulan Oktober hingga Desember 2015 di Laboratorium Kultur Jaringan Teknologi Benih Fakultas Pertanian Universitas Padjadjaran. Rancangan percobaan menggunakan Rancangan Acak Lengkap (RAL) yang terdiri dari 8 perlakuan penggunaan jenis dan konsentrasi sitokinin yang berbeda $\left(2 \mathrm{mg} \mathrm{L}^{-1} \mathrm{BAP}, 4 \mathrm{mg} \mathrm{L}^{-1}\right.$ BAP, $2 \mathrm{mg} \mathrm{L}^{-1}$ 2-iP, $4 \mathrm{mg} \mathrm{L}^{-1}$ 2-iP, 0,08 $\mathrm{mg} \mathrm{L}^{-1}$ TDZ, 0,2 mg L-1 TDZ, $2 \mathrm{mg} \mathrm{L}^{-1} \mathrm{Kn}, 4 \mathrm{mg} \mathrm{L}^{-1} \mathrm{Kn}$ ). Hasil percobaan menunjukkan bahwa $2 \mathrm{mg} \mathrm{L}^{-1}$ BAP merupakan jenis sitokinin yang mampu menghasilkan tingkat multiplikasi yang tinggi pada peubah persentase eksplan bertunas (\%), dan tinggi tunas $(\mathrm{cm})$.

Kata kunci : Efektivitas · Kepok kuning · Multiplikasi · Pisang · Sitokinin · Tunas

\section{Pendahuluan}

Pisang merupakan komoditas buah yang paling banyak diproduksi dan dikonsumsi di Indonesia (Purwadaria, 2006). Saat ini pisang kepok banyak digunakan sebagai bahan baku pembuatan keripik pisang sehingga sangat potensial untuk dikembangkan. Kebutuhan akan buah pisang untuk kebutuhan dalam negeri meningkat sehingga diperlukan produktivitas yang tinggi dari setiap tanaman pisang yang di tanam. Menurut Kementerian Pertanian dalam BPSP (2015), dimana produksi buah pisang di Indonesia dari tahun 2010 sampai 2013 yaitu 5.755.073 ton, 6.132.695 ton, 6.189.043 ton, dan 6.279.279 ton, namun permintaan ekspor yang tinggi harus perlu diatasi oleh para produsen 
buah pisang di Indonesia. Menurut FAOSTAT (2011), tingkat produksi global di Indonesia masih terbilang cukup rendah yaitu 6,56 \% jika dibandingkan dengan negara India yang memiliki $27,43 \%$.

Teknik perbanyakan tanaman pisang dapat dilakukan secara konvensional dengan bonggol atau anakan tanaman, namun untuk menghasilkan bibit tanaman memerlukan waktu yang relatif lama (10-18 bulan) dan jumlah yang dihasilkannya terbatas yaitu dalam 1 (satu) rumpun pisang hanya menghasilkan 5-10 bibit tanaman per tahun (Oritz et al., 1995 dalam UNCTS, 2007). Salah satu alternatifnya adalah dengan teknik kultur in vitro yang menghasilkan bibit pisang bermutu dalam jumlah banyak, seragam dan dalam waktu singkat (Meldia dkk., 1996), sehingga dapat menunjang pengembangan bibit pisang berkualitas. Teknik mikropropagasi atau perbanyakan bibit pisang secara in vitro sampai menjadi tanaman utuh yang dapat ditanam di lapangan memerlukan waktu \pm 5 - 8 bulan bergantung pada vigor tanaman dalam mempertahankan hidupnya (Vardja and Vardja, 2001; Ferdous et al., 2015; Marlin, 2010).

Penggunaan media dasar Murashige \& Skoog (MS) memiliki pengaruh yang baik untuk pertumbuhan eksplan pada kultur jaringan beberapa varietas tanaman. Saad and Elshahed (2012), melaporkan bahwa pada media MS mengandung nitrat, amonium, kalsium serta unsur makro dan mikro lain yang dapat mempengaruhi pertumbuhan eksplan. Salah satu zat pengatur tumbuh yang berperan dalam meningkatkan tunas pada eksplan pisang adalah sitokinin (Kasutjianingati dan Boer, 2013). Sitokinin merupakan zat pengatur tumbuh (ZPT) yang berperan dalam proses pembelahan sel, pembentukan organ, dan pembentukan mata tunas tumbuhan (George et al., 2008). Menurut Rainiyati dkk. (2007), semakin tinggi konsentrasi sitokinin yang diberikan maka jumlah tunas yang terbentuk akan semakin bertambah, namun pembentukan masing-masing tunas dapat terhambat sehingga penentuan konsentrasi yang tepat sangat perlu diperhatikan untuk menghasilkan multiplikasi tunas pisang yang maksimal.

Pemberian sitokinin antara $0,1-10 \mathrm{mg} \mathrm{L}^{-1}$ mampu menginduksi pembentukan tunas sesuai spesifikasi kultivar (Pierik, 1987). Arinaitwe et al. (2000), membuktikan bahwa respons kultivar pisang terhadap BAP relatif signifikan dibandingkan dengan jenis sitokinin lainnya seperti $\mathrm{ZN}$, KN dan 2-iP, namun pada konsentrasi yang rendah TDZ dapat meningkatkan jumlah tunas pada pisang kultvar 'Ndiziwemiti'. Perlunya pengujian efektivitas ini dilakukan untuk menghindari pemberian konsentrasi yang berlebih, karena jika konsentrasi yang diberikan terlalu tinggi pada tanaman dapat menghambat pertumbuhan tunas. Ditinjau dari pemaparan tersebut, maka penelitian ini penting dilakukan untuk mendapatkan salah satu jenis sitokinin yang terbaik untuk meningkatkan laju multplikasi tunas mikro pisang secara in vitro.

\section{Bahan dan Metode}

Percobaan ini dilaksanakan di Laboratorium Kultur Jaringan Teknologi Benih, Fakultas Pertanian, Universitas Padjadjaran, Jatinangor. Waktu pelaksanaan penelitian ini dimulai pada bulan Oktober-Desember 2015.

Bahan tanam yang digunakan dalam percobaan ini adalah bagian potongan batang plantlet pisang var. Kepok Kuning yang berasal dari koleksi Balai Benih Induk Hortikultura, Pasirbanteng Tanjungsari Sumedang. Bahan-bahan lain yang digunakan adalah komposisi media dasar Murashige and Skoog (MS), agar $7 \mathrm{~g} \mathrm{~L}^{-1}, 3$ \% sukrosa $\quad\left(30 \mathrm{~g} \mathrm{~L}^{-1}\right)$, dan zat pengatur tumbuh golongan sitokonin BAP, 2-iP, TDZ dan Kinetin.

Percobaan dilaksanakan dengan metode eksperimental menggunakan Rancangan Acak Lengkap (RAL) yang terdiri dari 8 perlakuan dan diulang sebanyak 4 kali yaitu A $\left(2 \mathrm{mg} \mathrm{L}^{-1}\right.$ $\mathrm{BAP}) ; \mathrm{B}\left(4 \mathrm{mg} \mathrm{L}^{-1} \mathrm{BAP}\right) ; \mathrm{C}\left(2 \mathrm{mg} \mathrm{L}^{-1} 2-\mathrm{iP}\right) ; \mathrm{D}(4$ $\mathrm{mg} \mathrm{L}{ }^{-1} 2$-iP); $\mathrm{E}\left(0,08 \mathrm{mg} \mathrm{L}^{-1} \mathrm{TDZ}\right) ; \mathrm{F}\left(0,2 \mathrm{mg} \mathrm{L}^{-1}\right.$ TDZ); $\mathrm{G}\left(2 \mathrm{mg} \mathrm{L}^{-1} \mathrm{Kn}\right)$ dan $\mathrm{H}\left(4 \mathrm{mg} \mathrm{L}^{-1} \mathrm{Kn}\right)$.

Eksplan yang diambil adalah bagian potongan batang yang telah diambil dari dalam botol dengan menggunakan pinset dan diletakkan dalam petridish steril, kemudian eksplan batang dipotong dengan ukuran panjang batang adalah $0,5 \mathrm{~cm}$ menggunakan scalpel. Eksplan yang ditanam selanjutnya diinkubasikan di dalam ruang kultur dengan penyinaran cahaya selama 16 jam dan suhu $21-22{ }^{\circ} \mathrm{C}$ selama 12 MST dengan tata letak percobaan yang sudah dibuat.

Data hasil percobaan pada parameter penunjang dianalisis secara kualitatif yaitu meliputi data visual dan dianalisis menggunakan metode deskriptif, sedangkan data kuantitatif pada parameter utama percobaan dianalisis menggunakan analisis ragam berdasarkan uji $\mathrm{F}$ taraf 5\%. Apabila terdapat beda nyata dilanjutkan dengan Uji Scott Knott pada taraf 5\%. 


\section{Hasil dan Pembahasan}

Persentase Eksplan Bertunas (\%). Hasil analisis ragam menunjukkan bahwa penggunaan berbagai jenis sitokinin memberikan pengaruh yang tidak berbeda nyata terhadap persentase eksplan bertunas pada umur 4 MST, 8 MST dan 12 MST (Tabel 1.).

Tabel 1. Kemampuan Eksplan Bertunas (\%) pada Berbagai Media Perlakuan pada Umur 4 MST, 8 MST dan 12 MST.

\begin{tabular}{|c|c|c|c|}
\hline \multirow{2}{*}{ Perlakuan } & \multicolumn{3}{|c|}{ Eksplan Bertunas (\%) } \\
\hline & $4 \mathrm{MST}$ & $8 \mathrm{MST}$ & 12 MST \\
\hline $\mathrm{A}\left(2 \mathrm{mg} \mathrm{L}^{-1} \mathrm{BAP}\right)$ & $66,67 \mathrm{a}$ & $75,00 \mathrm{a}$ & $75,00 \mathrm{a}$ \\
\hline B (4 mg L-1 BAP) & $50,00 \mathrm{a}$ & $50,00 \mathrm{a}$ & $50,00 \mathrm{a}$ \\
\hline $\mathrm{C}\left(2 \mathrm{mg} \mathrm{L}^{-1} 2-\mathrm{iP}\right)$ & $47,92 \mathrm{a}$ & $62,50 \mathrm{a}$ & $62,50 \mathrm{a}$ \\
\hline $\mathrm{D}\left(4 \mathrm{mg} \mathrm{L} \mathrm{L}^{-1} 2-\mathrm{iP}\right)$ & $68,75 \mathrm{a}$ & $60,42 \mathrm{a}$ & $66,67 \mathrm{a}$ \\
\hline \multicolumn{4}{|l|}{$\mathrm{E}\left(0,08 \mathrm{mg} \mathrm{L}^{-1}\right.$} \\
\hline TDZ) & $50,00 \mathrm{a}$ & $50,00 \mathrm{a}$ & $62,50 \mathrm{a}$ \\
\hline $\mathrm{F}\left(0,2 \mathrm{mg} \mathrm{L}^{-1} \mathrm{TDZ}\right)$ & $41,67 \mathrm{a}$ & $50,00 \mathrm{a}$ & $50,00 \mathrm{a}$ \\
\hline $\mathrm{G}\left(2 \mathrm{mg} \mathrm{L}^{-1} \mathrm{Kn}\right)$ & $56,25 \mathrm{a}$ & $68,75 \mathrm{a}$ & $75,00 \mathrm{a}$ \\
\hline $\mathrm{H}\left(4 \mathrm{mg} \mathrm{L}^{-1} \mathrm{Kn}\right)$ & $64,58 \mathrm{a}$ & $62,50 \mathrm{a}$ & $62,50 \mathrm{a}$ \\
\hline
\end{tabular}

Keterangan : Nilai rata-rata yang diikuti oleh huruf yang sama tidak berbeda nyata menurut Uji Duncan pada taraf 5\%. MST = Minggu Setelah Tanam.

Kemampuan eksplan bertunas dipengaruhi oleh genotip tanaman, namun terlepas dari pengaruh genotip tanaman, dalam meningkatkan multiplikasi tunas (proliferasi) dipengaruhi oleh jenis sitokinin dan konsentrasi yang digunakan (Strosse et al., 2004). Pengaruh konsentrasi eksogen menurut Ngomou et al. (2013), menjadi faktor utama dalam kegiatan perbanyakan tersebut untuk mendapatkan tingkat multiplikasi tanaman yang optimal.

Penggunaan sitokinin $2 \mathrm{mg} \mathrm{L}^{-1} \mathrm{BAP}, 0,08$ mg L-1 TDZ, $2 \mathrm{mg} \mathrm{L}^{-1} \mathrm{Kn}$ memperlihatkan persentase eksplan bertunas yang cenderung lebih tinggi jika dibandingkan dengan penggunaan konsentrasi tinggi (Gambar 1). Menurut George et al. (2008), pemberian sitokinin dengan konsentrasi rendah dapat memberikan respon pertumbuhan tunas aksilar maupun tunas adventif karena kandungan sitokinin endogen sudah mencukupi, selain itu Ngomuo et al. (2014) menyatakan bahwa rendahnya pertumbuhan eksplan membentuk tunas diduga karena eksplan sangat bergantung dengan faktor endogen eksplan itu sendiri, selain itu terjadi peranan zat pengatur tumbuh bila kondisi fisiologi eksplan dalam keadaan prima.

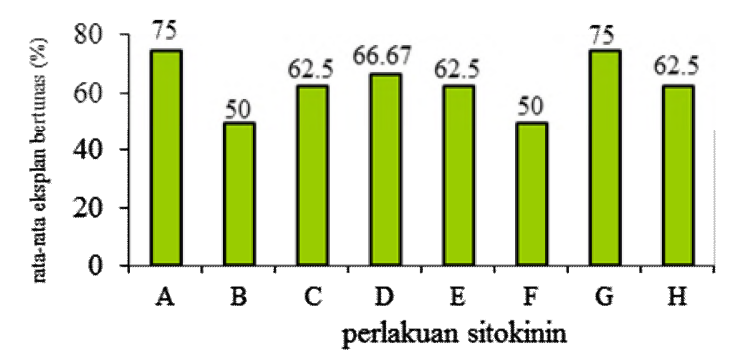

Ket : A $=2 \mathrm{mg} \mathrm{L}^{-1} \mathrm{BAP}, \mathrm{B}=4 \mathrm{mg} \mathrm{L}^{-1} \mathrm{BAP}, \mathrm{C}=2 \mathrm{mg} \mathrm{L}^{-1}$ 2-iP, $\mathrm{D}=4 \mathrm{mg} \mathrm{L}^{-1} 2-\mathrm{iP}, \mathrm{E}=0,08 \mathrm{mg} \mathrm{L}^{-1} \mathrm{TDZ}, \mathrm{F}=0,2$ $m g L^{-1} \mathrm{TDZ}, \mathrm{G}=2 \mathrm{mg} \mathrm{L}^{-1} \mathrm{Kn}, \mathrm{H}=4 \mathrm{mg} \mathrm{L}^{-1} \mathrm{Kn}$.

\section{Gambar 1. Perbandingan Rata-rata Persentase Eksplan Bertunas Umur 12 MST.}

Waktu Terbentuknya Tunas (HST). Hasil analisis ragam pada peubah waktu terbentuknya tunas menunjukkan pengaruh berbeda nyata (Tabel 2).

Tabel 2. Pengaruh Berbagai Jenis dan Konsentrasi Sitokinin terhadap Waktu Terbentuknya Tunas Mikro Pisang.

\begin{tabular}{lc}
\hline \hline \multicolumn{1}{c}{ Perlakuan } & Rata-rata (HST) \\
\hline A (2 mg L-1 BAP) & $4,00 \mathrm{ab}$ \\
B (4 mg L-1 BAP) & $7,38 \mathrm{ab}$ \\
C (2 mg L-1 2-iP) & $2,38 \mathrm{ab}$ \\
D (4 mg L-1 2-iP) & $7,75 \mathrm{ab}$ \\
E (0,08 mg L-1 $\mathrm{TDZ})$ & $12,25 \mathrm{~b}$ \\
F $\left(0,2 \mathrm{mg} \mathrm{L}^{-1} \mathrm{TDZ}\right)$ & $1,50 \mathrm{a}$ \\
$\mathrm{G}\left(2 \mathrm{mg} \mathrm{L}^{-1} \mathrm{Kn}\right)$ & $5,42 \mathrm{ab}$ \\
$\mathrm{H}\left(4 \mathrm{mg} \mathrm{L}^{-1} \mathrm{Kn}\right)$ & $3,75 \mathrm{ab}$ \\
\hline \hline
\end{tabular}

Keterangan : Nilai rata-rata yang diikuti oleh huruf yang sama tidak berbeda nyata menurut Uji Duncan pada taraf 5\%. HST = Hari Setelah Tanam.

Waktu terbentuknya tunas berdasarkan percobaan ini memerlukan rata-rata waktu pada hari 1 HST- 15 HST. Hal ini sesuai dengan pernyataan Qamar et al. (2015), waktu yang dibutuhkan untuk pembentukan tunas adalah 10-20 hari pada tanaman pisang.

Pembentukan tunas mikro ini diawali dengan adanya pembengkakan atau penebalan pada bagian bawah potongan batang yang ditanam. Pembengkakan pada eksplan yang terjadi disebabkan terdapatnya aktivitas auksin endogen yang cukup untuk memobilisasi sel-sel untuk membentuk individu-individu baru (tunas) (Rainiyati dkk. 2009), hal ini berkaitan dengan peranan auksin dapat menginduksi pembesaran sel yang cepat karena hasil aktivasi dari ATP-ase yang memompa proton di membran sel, aktivasi ekspansi sel (peningkatan 
ukuran sel) dan melonggarkan dinding sel sehingga terjadi pembesaran sel (pembengkakan sel) (Perrot-Rechenmann 2010).

Jumlah Tunas Mikro. Hasil analisis ragam menunjukkan pengaruh yang tidak berbeda nyata dari masing-masing perlakuan terhadap jumlah tunas seperti yang terlihat pada Tabel 3.

Tabel 3. Pengaruh Berbagai Media Perlakuan pada Umur 4, 8, 12 MST terhadap Jumlah Tunas (buah).

\begin{tabular}{|c|c|c|c|}
\hline \multirow{2}{*}{ Perlakuan } & \multicolumn{3}{|c|}{ Jumlah Tunas (buah) } \\
\hline & 4 MST & 8 MST & $12 \mathrm{MST}$ \\
\hline $\mathrm{A}\left(2 \mathrm{mg} \mathrm{L}^{-1} \mathrm{BAP}\right)$ & $1,00 \mathrm{a}$ & $1,08 \mathrm{a}$ & $1,58 \mathrm{a}$ \\
\hline $\mathrm{B}\left(4 \mathrm{mg} \mathrm{L}^{-1} \mathrm{BAP}\right)$ & $1,00 \mathrm{a}$ & $1,63 \mathrm{a}$ & $1,63 \mathrm{a}$ \\
\hline $\mathrm{C}\left(2 \mathrm{mg} \mathrm{L}^{-1} 2-\mathrm{iP}\right)$ & $0,75 \mathrm{a}$ & $0,75 \mathrm{a}$ & $0,75 \mathrm{a}$ \\
\hline $\mathrm{D}\left(4 \mathrm{mg} \mathrm{L}^{-1} 2-\mathrm{iP}\right)$ & $1,00 \mathrm{a}$ & $1,17 \mathrm{a}$ & $1,33 \mathrm{a}$ \\
\hline $\mathrm{E}\left(0,08 \mathrm{mg} \mathrm{L}^{-1} \mathrm{TDZ}\right)$ & $1,00 \mathrm{a}$ & $1,00 \mathrm{a}$ & $1,00 \mathrm{a}$ \\
\hline $\mathrm{F}\left(0,2 \mathrm{mg} \mathrm{L}^{-1} \mathrm{TDZ}\right)$ & $0,88 \mathrm{a}$ & $1,00 \mathrm{a}$ & $1,00 \mathrm{a}$ \\
\hline $\mathrm{G}\left(2 \mathrm{mg} \mathrm{L}^{-1} \mathrm{Kn}\right)$ & $0,75 \mathrm{a}$ & $0,75 \mathrm{a}$ & $1,50 \mathrm{a}$ \\
\hline $\mathrm{H}\left(4 \mathrm{mg} \mathrm{L}^{-1} \mathrm{Kn}\right)$ & $1,00 \mathrm{a}$ & $1,00 \mathrm{a}$ & $1,25 \mathrm{a}$ \\
\hline
\end{tabular}

Keterangan : Nilai rata-rata yang diikuti oleh huruf yang sama tidak berbeda nyata menurut Uji Duncan pada taraf $5 \%$.

MST = Minggu Setelah Tanam

Jumlah tunas yang berbeda-beda diduga dipengaruhi oleh kemampuan eksplan dalam menyerap unsur hara yang ada di dalam media MS dan zat pengatur tumbuh yang diberikan (Gambar 2). Menurut Ferdous et al. (2015), semakin tinggi konsentrasi sitokinin yang diberikan pada tanaman maka akan menghasilkan jumlah tunas yang banyak. Menurut George et al. (2008), aplikasi pemberian sitokinin tunggal mampu menghasilkan tunas yang maksimal, namun pada konsentrasi tertentu akan menghasilkan kelainan pada tunas yang diperoleh.
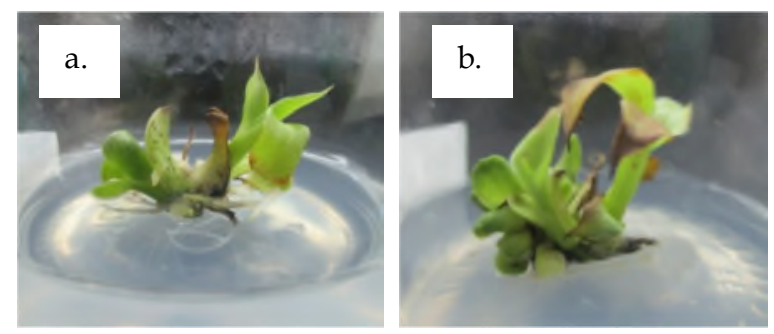

Gambar 2. Eksplan yang menghasilkan tunas majemuk.

a. media $B=4 \mathrm{mg} \mathrm{L}^{-1} \mathrm{BAP}$

b. media $\mathrm{F}=0,2 \mathrm{mg} \mathrm{L}^{-1} \mathrm{TDZ}$

Reddy et al. (2014), menyatakan bahwa hormon pengatur tumbuh seperti sitokinin dapat mengatur proses fisiologis tanaman walau- pun dengan pemberian konsentrasi rendah. Hal ini disebabkan karena aktivitas sitokinin yang terkait dengan proses pertumbuhan dan perkembangan dalam siklus sel, khususnya untuk melakukan metabolisme asam nukleat dan sintesis protein (Adds et al., 2004).

Tinggi Tunas (cm). Tabel 4. menunjukkan adanya pengaruh dari media perlakuan terhadap tinggi tunas pada umur 4, namun tidak terdapat pengaruh pada umur 8 dan 12 MST.

Tabel 4. Pengaruh berbagai Jenis dan Konsentarsi Sitokinin terhadap Tinggi Tunas Umur 4, 8, 12 MST.

\begin{tabular}{|c|c|c|c|}
\hline \multirow{2}{*}{ Perlakuan } & \multicolumn{3}{|c|}{ Tinggi Tunas $(\mathrm{cm})$} \\
\hline & $4 \mathrm{MST}$ & $8 \mathrm{MST}$ & $12 \mathrm{MST}$ \\
\hline $\mathrm{A}\left(2 \mathrm{mg} \mathrm{L}^{-1} \mathrm{BAP}\right)$ & $0,98 \mathrm{~b}$ & $2,62 \mathrm{a}$ & $2,62 \mathrm{a}$ \\
\hline $\mathrm{B}\left(4 \mathrm{mg} \mathrm{L}^{-1} \mathrm{BAP}\right)$ & $0,34 \mathrm{a}$ & $0,91 \mathrm{a}$ & $1,00 \mathrm{a}$ \\
\hline $\mathrm{C}\left(2 \mathrm{mg} \mathrm{L} \mathrm{L}^{-1} 2-\mathrm{iP}\right)$ & $0,42 \mathrm{a}$ & $1,96 \mathrm{a}$ & $1,96 \mathrm{a}$ \\
\hline $\mathrm{D}\left(4 \mathrm{mg} \mathrm{L}^{-1} 2-\mathrm{iP}\right)$ & $0,68 \mathrm{ab}$ & $2,59 a$ & $2,59 \mathrm{a}$ \\
\hline $\mathrm{E}\left(0,08 \mathrm{mg} \mathrm{L}^{-1} \mathrm{TDZ}\right)$ & $0,73 \mathrm{ab}$ & $1,40 \mathrm{a}$ & $2,31 \mathrm{a}$ \\
\hline $\mathrm{F}\left(0,2 \mathrm{mg} \mathrm{L}^{-1} \mathrm{TDZ}\right)$ & $0,28 \mathrm{a}$ & $1,06 \mathrm{a}$ & $1,06 \mathrm{a}$ \\
\hline $\mathrm{G}\left(2 \mathrm{mg} \mathrm{L}^{-1} \mathrm{Kn}\right)$ & $0,49 \mathrm{ab}$ & 1,81 a & $1,84 \mathrm{a}$ \\
\hline $\mathrm{H}\left(4 \mathrm{mg} \mathrm{L}^{-1} \mathrm{Kn}\right)$ & $0,60 \mathrm{ab}$ & $1,53 \mathrm{a}$ & $1,54 \mathrm{a}$ \\
\hline
\end{tabular}

Ket. : Nilai rata-rata yang diikuti oleh huruf yang sama tidak berbeda nyata menurut Uji Duncan pada taraf $5 \%$. MST $=$ Minggu Setelah Tanam

Pengaruh nyata mulai terlihat pada umur 4 MST terdapat pengaruh nyata, dimana pada perlakuan $2 \mathrm{mg} \mathrm{L}^{-1}$ BAP (A) memberikan pengaruh yang baik, sedangkan pada 8 dan 12 MST tidak terjadi pengaruh yang berbedanyata, hal ini diduga karena pada umur tersebut pertambahan tinggi tunas sudah mulai terhenti. Penyebab lainnya juga diakibatkan dari pertambahan tunas mikro baru sehingga pertumbuhan dan perkembangan eksplan dipusatkan pada tunas mikro tersebut. Proses proliferasi tunas dan perpanjangan dipengaruhi oleh sitokinin dan konsentrasi yang digunakan (Strosse, et al., 2004).

Pertumbuhan tinggi tunas ini terjadi kecenderungan dimana semakin banyak jumlah tunas yang tumbuh pada eksplan dari setiap perlakuan mengakibatkan rata-rata tinggi tunas menjadi lebih rendah. Ramesh dan Ramassamy (2014), menyatakan tinggi tanaman diduga dipengaruhi oleh jumlah tunas yang muncul, sehingga semakin sedikit tunas yang muncul, maka tinggi tanaman semakin meningkat, dan sebaliknya, hal ini karena energi yang dibutuhkan untuk pemanjangan tunas digunakan untuk pembentukan calon tunas lainnya, sehingga tinggi tunas dapat mengalami penghambatan. 
Menurut Lu (2005), sitokinin akan memacu pembelahan sel dan menghambat elongasi (perpanjangan), sehingga yang banyak terbentuk adalah tunas, sedangkan elongasi tunasnya dihambat. Penggunaan konsentrasi sitokinin yang lebih tinggi dapat menghambat pemanjangan meristem adventif dan konversi menjadi tanaman lengkap (Buising et al., 1994).

Jumlah Daun (helai). Hasil analisis ragam media perlakuan pada jumlah daun memberikan pengaruh yang tidak berbeda nyata pada umur 4, 8 dan 12 MST dapat dilihat pada Tabel 5.

Semakin sedikit jumlah tunas yang terbentuk, maka dapat menghasilkan jumlah daun yang lebih banyak, contohnya pada perlakuan $\mathrm{E}\left(0,08 \mathrm{mg} \mathrm{L}^{-1} \mathrm{TDZ}\right)$ yang mampu menghasilkan jumlah daun yang cukup banyak dengan rata-rata adalah 4,50 helai daun (Tabel 5), sejalan dengan pernyataan Demissie (2013), jumlah daun dipengaruhi oleh jumlah tunas yang muncul, sehingga semakin sedikit tunas yang muncul, maka jumlah daun yang terbentuk akan semakin banyak dan sebaliknya.

Tabel 5. Pengaruh Berbagai Jenis dan Konsentrasi Sitokinin terhadap Jumlah Daun pada Umur 4, 8 dan 12 MST .

\begin{tabular}{|c|c|c|c|}
\hline \multirow{2}{*}{ Perlakuan } & \multicolumn{3}{|c|}{ "Jumlah Daun (helai) } \\
\hline & 4 MST & $8 \mathrm{MST}$ & $12 \mathrm{MST}$ \\
\hline $\mathrm{A}\left(2 \mathrm{mg} \mathrm{L}^{-1} \mathrm{BAP}\right)$ & $1,75 \mathrm{a}$ & $3,17 \mathrm{a}$ & $3,17 \mathrm{a}$ \\
\hline $\mathrm{B}\left(4 \mathrm{mg} \mathrm{L}^{-1} \mathrm{BAP}\right)$ & $0,75 \mathrm{a}$ & $1,50 \mathrm{a}$ & $2,00 \mathrm{a}$ \\
\hline $\mathrm{C}\left(2 \mathrm{mg} \mathrm{L}^{-1} 2-\mathrm{iP}\right)$ & $0,50 \mathrm{a}$ & $2,75 \mathrm{a}$ & $2,75 \mathrm{a}$ \\
\hline $\mathrm{D}\left(4 \mathrm{mg} \mathrm{L}^{-1} 2-\mathrm{iP}\right)$ & $1,29 \mathrm{a}$ & $2,63 a$ & $3,80 \mathrm{a}$ \\
\hline $\mathrm{E}\left(0,08 \mathrm{mg} \mathrm{L}^{-1} \mathrm{TDZ}\right)$ & $1,75 \mathrm{a}$ & $2,25 \mathrm{a}$ & $4,50 \mathrm{a}$ \\
\hline $\mathrm{F}\left(0,2 \mathrm{mg} \mathrm{L}^{-1} \mathrm{TDZ}\right)$ & $0,88 \mathrm{a}$ & $1,50 \mathrm{a}$ & $1,50 \mathrm{a}$ \\
\hline $\mathrm{G}\left(2 \mathrm{mg} \mathrm{L}^{-1} \mathrm{Kn}\right)$ & $0,63 \mathrm{a}$ & $2,25 \mathrm{a}$ & $3,25 \mathrm{a}$ \\
\hline $\mathrm{H}\left(4 \mathrm{mg} \mathrm{L}^{-1} \mathrm{Kn}\right)$ & $0,50 \mathrm{a}$ & $2,25 \mathrm{a}$ & $3,25 \mathrm{a}$ \\
\hline
\end{tabular}

Ket. : Angka-angka yang diikuti huruf yang sama pada setiap kolom tidak berbeda nyata menurut Uji Duncan pada Taraf nyata $5 \%$. MST = Minggu Setelah Tanam.

Penggunaan sitokinin jenis TDZ dengan konsentrasi yang lebih tinggi menghasilkan ratarata jumlah daun yang relatif rendah. Farhani et al. (2008), menyatakan bahwa TDZ dengan konsentrasi tinggi dapat menurunkan jumlah tunas, hal ini diduga menyebabkan penurunan jumlah daun yang terbentuk karena pada eksplan tidak dapat menghasilkan tunas yang nantinya akan berkembang menjadi tanaman baru (plantlet) dan memiliki perkembangan serta jumlah daun yang tinggi, selain itu Razani et al. (2012), menyatakan bahwa pada konsentrasi TDZ yang tinggi akan banyak menghasilkan tunas abnormal.
Persentase Eksplan Berakar (\%). Perlakuan sitokinin mampu menghasilkan akar walaupun eksplan tidak diinisiasi ke dalam media perakaran. Hasil perhitungan dengan analisis ragam menunjukkan bahwa media perlakuan pada peubah persentase eksplan berakar tidak memberikan pengaruh yang berbeda nyata umur 4, 8, dan 12 MST (Tabel 6.).

Tabel 6. Pengaruh berbagai Jenis dan Konsentrasi Sitokinin terhadap Persentase Eksplan Berakar (\%) pada Umur 4, 8, dan 12.

\begin{tabular}{|c|c|c|c|}
\hline \multirow{2}{*}{ Perlakuan } & \multicolumn{3}{|c|}{ Eksplan Berakar (\%) } \\
\hline & 4 MST & $8 \mathrm{MST}$ & $12 \mathrm{MST}$ \\
\hline $\mathrm{A}\left(2 \mathrm{mg} \mathrm{L}^{-1} \mathrm{BAP}\right)$ & $58,33 \mathrm{a}$ & $83,33 \mathrm{a}$ & $100,00 \mathrm{a}$ \\
\hline $\mathrm{B}\left(4 \mathrm{mg} \mathrm{L}^{-1} \mathrm{BAP}\right)$ & $25,00 \mathrm{a}$ & $37,50 \mathrm{a}$ & $50,00 \mathrm{a}$ \\
\hline $\mathrm{C}\left(2 \mathrm{mg} \mathrm{L}^{-1} 2-\mathrm{iP}\right)$ & $14,58 \mathrm{a}$ & $50,00 \mathrm{a}$ & $50,00 \mathrm{a}$ \\
\hline $\mathrm{D}\left(4 \mathrm{mg} \mathrm{L}^{-1} 2-\mathrm{iP}\right)$ & $50,00 \mathrm{a}$ & $79,17 \mathrm{a}$ & $100,00 \mathrm{a}$ \\
\hline $\mathrm{E}\left(0,08 \mathrm{mg} \mathrm{L}^{-1} \mathrm{TDZ}\right)$ & $20,83 \mathrm{a}$ & $25,00 \mathrm{a}$ & $25,00 \mathrm{a}$ \\
\hline $\mathrm{F}\left(0,2 \mathrm{mg} \mathrm{L}^{-1} \mathrm{TDZ}\right)$ & $54,17 \mathrm{a}$ & $62,50 \mathrm{a}$ & $62,50 \mathrm{a}$ \\
\hline $\mathrm{G}\left(2 \mathrm{mg} \mathrm{L}^{-1} \mathrm{Kn}\right)$ & $12,50 \mathrm{a}$ & $37,50 \mathrm{a}$ & 41,67 a \\
\hline $\mathrm{H}\left(4 \mathrm{mg} \mathrm{L}{ }^{-1} \mathrm{Kn}\right)$ & $12,50 \mathrm{a}$ & $75,00 \mathrm{a}$ & $75,00 \mathrm{a}$ \\
\hline
\end{tabular}

Ket. : Angka-angka yang diikuti huruf yang sama pada setiap kolom tidak berbeda nyata menurut Uji Duncan pada Taraf nyata $5 \%$. MST $=$ Minggu Setelah Tanam.

Gambar 3. menunjukkan terjadinya kecenderungan kemampuan eksplan membentuk akar pada setiap perlakuan. Setiap perlakuan yang diuji cenderung mengalami peningkatan dalam menghasilkan akar. Media perlakuan A dan D dapat menghasilkan perakaran yang relatif lebih baik, jika dibandingkan dengan perlakuan lainnya.

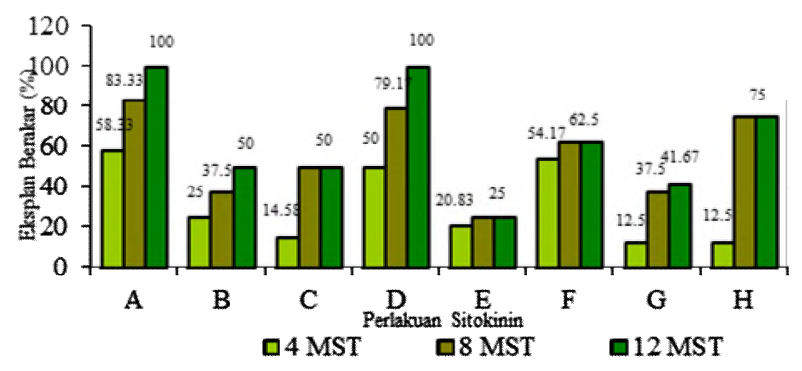

Gambar 3. Data Presentase Eksplan Berakar (\%) pada umur 4, 8, dan 12 MST.

Menurut Su et al. (2011), media tanpa penambahan sitokinin lebih baik jika dibandingkan dengan media yang mengandung sitokinin untuk pembentukan akar, hal ini karena sitokinin dapat menghambat biosistensis auksin endogen dalam membentuk akar. Pada pengamatan selama percobaan berlangsung, terdapat beberapa eksplan yang menghasilkan akar namun tidak membentuk tunas (Gambar 
4a.). Keadaan ini terjadi diduga adanya kandungan hormon auksin endogen dalam eksplan mungkin cukup tinggi untuk menumbuhkan akar eksplan (Rodinah dkk., 2012), selain itu menurut Mahonen et al. (2006), pengaruh pemberian sitokinin dapat ditekan atau dihambat di dalam sel xylem sehingga sel pembentukan akar dapat terlindungi dari pengaruh sitokinin dalam sel tersebut.
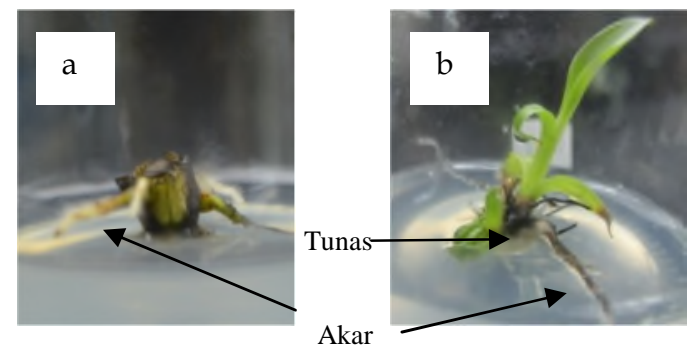

Gambar 4. Kondisi Eksplan Berakar.

a) eksplan yang tidak bertunas namun berakar, b) eksplan yang bertunas dan berakar.

Eksplan-eksplan yang telah membentuk tunas sebagian besar mampu menghasilkan akar (Gambar 4b.), hal ini diduga karena adanya tunas yang tumbuh mampu memproduksi auksin endogen. Menurut Wang et al. (2002), sitokinin dapat merangsang produksi etilen dalam kondisi tertentu, dimana etilen dapat merangsang pembentukan akar adventif dengan mensintesis bagian tanaman yang terluka dan menjadikanya sebagai tempat pembentukan akar adventif pada bagian atau jaringan yang terluka akibat kegiatan pemotongan eksplan (Kuroha dan Satoh, 2006).

\section{Kesimpulan}

1. Terdapat pengaruh lebih baik pada pemberian jenis dan konsentrasi sitokinin terhadap waktu terbentuknya tunas dan tinggi tunas pada eksplan pisang kepok kuning.

2. Penggunaan $2 \mathrm{mg} \mathrm{L}^{-1}$ BAP mampu menghasilkan tingkat multiplikasi yang tinggi berdasarkan pada peubah persentase eksplan bertunas (\%) dan tinggi tunas (cm)

Saran Penelitan perlu dilakukan lebih lanjut untuk proses pembesaran, perakaran, aklimatisasi, pengujian evaluasi bebas dari virus dan/atau penyakit, serta pengujian evaluasi pertumbuhan dan hasil di lapangan dengan menggunakan tanaman pisang asal in vitro.

\section{Daftar Pustaka}

Adds, J., E. Larkcom, and R. Miller. 2004. Genetics, Evolution, and Biodiversity. Nelson Advanced Science. United Kingdom, pp. 184.

Arinaitwe, G., P.R. Rubaihayo, and M.J.S. Magambo. 2000. Proliferation rate effects of cytokinins on banana (Musa spp.) cultivars. Sci. Hortic. 86:13-21

Badan Pusat Statistika Pertanian (BPSP). 2015. Data Hortikultura : Kementrian Pertanian. Tersedia online di http://aplikasi.pertanian. go.id/bdsp/hasil_kom.asp

Buising, C. M., R. C. Shoemaker, and R. M. Benbow. 1994. Early events of multiple bud formation and shoot development in soybean embryonic axes treated with the cytokinin, 6-benzylaminopurine. Am. J. Bot. 81(1): 1435-1448. Availabe on online at http:/ / dx.doi.org/10.2307/2445317

Demissie, A.G. 2013. Effect of different combinations of BAP (6-benzyl amino purine) and NAA (Napthalene acetic acid) on multiple shoot proliferation of plantain (Musa spp.) cv. Matoke from meristem derived explant. Academia J. Biotech. 1(5): 2315-7747.

FAOSTAT. 2011. Top Production - Banana. Tersedia online http://faostat.fao.org/site/ 339/default.aspx. Diakses 19 Sept. 2015.

Farhani, F., H. Aminpoor, M. Sheidai, Z. Noormohammadi, and M.H. Mazinani. 2008. An improved system for in vitro propagation of banana (Musa acuminate L.) cultivars. Asian Journal of Plant Science 7(1): 116-118.

Ferdous, M.H., A.A.M. Billah, H. Mehraj, T. Taufique, and A.F.M.J. Uddin. 2015. BAP and IBA pulsing for in vitro multiplication of banana cultivars through shoot-tip culture. J.Bioscie. Agri. Research 3(2): 87-95.

George, E.F., M.A. Hall, and G.D. Klerk. 2008. Plant Growth Regulators II : Cytokinins, their Anologues and Antagonists. Plant Propagation by Tissue Culture 3rd Edition, pp. 205226.

Kasutjianingati., dan D. Boer. 2013. Mikropropagasi pisang mas kirana (musa acuminate 1.) Memanfaatkan BAP dan NAA secara in vitro. Jurnal Agroteknos 3(1): 60-64.

Kuroha, T., and S. Satoh. 2006. Involvement of Cytokinins in adventitious and lateral root formation. Plant Root (JSRR) 1: 27-33. Available online at www.plantroot.org. 
Lu, M. C. 2005. Micropropagation of Vitis thunbergii Sieb. et Zucc, a medicinal herb, through high-frequency shoot tip culture. Scie. Hort. 107: 64-69

Mahonen, A.P., A. Bishopp, M. Higuchi, K.M. Nieminen, K. Kinoshita, K. Tormakangas, Y. Ikeda, A. Oka, T. Kakimoto, and Y. Helariutta. 2006. Cytokinin signaling and its inhibitor AHP6 regulate cell fate during vascular development. Science 311: 94-98.

Marlin. 2010. Regenerasi in vitro plantlet pisang ambon curup melalui pembentukan kalus embriogenik. Pros. Semirata Bidang Ilmuilmu Pertanian, hal. 468-474.

Meldia, Y.S., A. Sunyoto, dan Suprianto. 1996. Pembibitan tanaman pisang. Solok : Balai Penelitian Tanaman Buah.

Ngomuo, M., E. Mneney, and P. Ndakidemi. 2013. The effect of auxins and cytokinin on growth and development of (Musa sp.) var. "Yangambi" explanted in tissue culture. American J. Plant Sciences 4 : 2174-2180.

Perrot-Rechenmann, C. 2010. Cellular responses to auxin : division versus expansion. Cold Spring Harbor Perspectives in Biology 2 : 115. Available on online at http:// cshperspectives.cshlp.org/

Pierik, R. L. M. 1987. In vitro Culture of Higher Plants. Netherlands : Martinus Nijhoff Publisher, P. 344

Purwadaria, H.K. 2006. Issues and solutions of fresh fruits export in Indonesia. Department of Agricultural Engineering, Bogor Agricultural University. Indonesia.

Qamar, M., S.T. Qureshi, I.A. Khan, and S. Raza. 2015. Optimization of in vitro multiplication for exotic banana (musa spp.) In pakistan. African J. Biotech. 14(24): 1989-1995. Availabe online at http://www.academicjournals.ora/AJB

Rainiyati, Lizawati, dan M. Kristiana. 2009. Peranan IAA dan BAP terhadap perkembangan nodul pisang (Musa $A A B)$ raja nangka secara in vitro. Jurnal Agronomi 13(1): 51-57.

Rainiyati., D. Martino., gusniawati., dan Jaminarni. 2007. Perkembangan Pisang Raja Nangka (Musa sp.) secara kultur jarngan dari eksplan anakan dan meristem bunga. Jurnal Agronomi 11(1): 35-39
Ramesh, Y., and V. Ramassamy. 2014. Effect of gelling agents in in vitro multiplication of banana var. Poovan. Int. J. Advanced Bio. research 4(3): 308-311.

Razani, M., N.A Shaharuddin, S. Subramaniam, and M. Mahmood. 2012. Effects of tdz on morphological and biochemical changes of banana plantlets (Musa spp.) Cultivar mas cultured in temporary immersion bioreactor system. Malaysia : Dept. of Biochemistry, Faculty of Biotechnology and Biomolecular Sciences, Universitas Putra Malaysia, Internatonal Banana Symposium.

Reddy, D.R.D., D. Suvarna, and D.M. Rao. 2014. Effects of 6-Benzyl Amino Purine (6-BAP) on In Vitro Shoot Multiplication of Grand Naine (Musa sp.). Int. J. advanced Biotech. \& research 5(1): 36-42.

Rodinah, C. Nina, dan E. Rohmayanti. 2012. Inisiasi pisang talas (Musa paradisiacal var sapientum L.) dengan pemberian sitokinin secara in vitro. Agroscientiae 19(2): 107-111.

Saad, A.I.M., and A.M. Elshahed. 2012. Chapter II : Plant Tissue Culture Media. Intech, pp 29-40.

Strosse, H., I. Van den Houwe, and B. Panis. 2004. Banana cell and tissue culture: cellular, molecular biology and induced mutations. Polymouth, U.K.: Science Publishers Inc, pp : 1-12.

Su, Y., Y. Liu, and X. Zhang. 2011. Auxincytoknin interaction regulates meristem development. Molecular Plant 4(4): 616-625. Available online at http://www.ncbi.nlm. nih.gov/pmc/articles/PMC3146736/

Uganda National Council for Science and Technology (UNCTS). 2007. The Biology of Bananas and Plantains. Uganda National Council for Science and Technology (UNCTS) with Program for Biosafety System (PBS).

Vardja, R., and T. Vardja. 2001. The effect of cytokinin type and concentration and the number of subcultures on the multiplication rate of some decorative plants. Proc. Estonia Acad. Sci. Biol. Ecol. 50(1): 22-32

Wang, K.L., H. Li, and J.R. Ecker. 2002. Ethylene biosynthesis and signaling networks. Plant Cell 14: S131-S151. 